\title{
Alpha-glucosidase inhibitory activity and phytochemical investigation of Borassus flabellifer Linn.
}

\author{
Sukanya Dej-adisai*, Thanet Pitakbut and Chatchai Wattanapiromsakul \\ Department of Pharmacognosy and Pharmaceutical Botany, Faculty of Pharmaceutical Sciences, Prince of Songkla \\ University, Hat-Yai, Songkhla, Thailand.
}

Received 22 November 2016; Accepted 13 January, 2017

\begin{abstract}
The determination of $\alpha$-glucosidase inhibitory activity and isolation of active compounds from Borassus flabellifer Linn. are the main objectives of this study. The colorimetric method and chromatographic technique were done for bioassay and phytochemistry. The results showed that, at concentration of $2 \mathrm{mg} / \mathrm{ml}$, ethyl acetate extract inhibited $\alpha$-glucosidase equally as positive standard, acarbose as $80 \%$ while water and ethanol extracts showed lower activity. Four compounds were isolated as glucosyl-(6-1)-glycerol, mixture of $\beta$-sitosterol and stigmasterol, 5 -hydroxymethyl-furfural and tyrosol. In addition, 2 isolated compounds, tyrosol and glucosyl-(6-1)-glycerol showed moderate and mild $\alpha$-glucosidase inhibitory activities with $\mathrm{IC}_{50}$ as $1041.5 \pm 205.5 \mu \mathrm{g} / \mathrm{ml}$ and $30 \%$ inhibition at 1000 $\mu \mathrm{g} / \mathrm{ml}$, respectively when compared with acarbose $\left(\mathrm{IC}_{50}=125.6 \pm 9.3 \mu \mathrm{g} / \mathrm{ml}\right)$. Since, $B$. flabellifer extract and the isolated compounds, tyrosol and glucosyl-(6-1)-glycerol exhibited $\alpha$-glucosidase inhibition, this plant can be further subjected to in vivo anti-diabetic studies.
\end{abstract}

Key words: a-Glucosidase inhibitor, Borassus flabellifer, tyrosol, glucosyl-(6-1)-glycerol, anti-diabetes.

\section{INTRODUCTION}

Diabetes mellitus is one of the most important diseases in group of non-communicative diseases (NCD). In recent reports, the number of diabetic patients would dramatically increase from around 400 million in 2013 to almost 600 million in 2035 (Guariguata et al., 2014). In addition, diabetes could lead to the other chronic diseases such as hypertension and diabetes itself and also has serious complications including loss of vision or can cause life threatening event and hyperglycemic shock (Chan et al., 2014). Inhibition of a-glucosidase is one of anti-diabetes strategies and it has been used clinically. Alpha-glucosidase is involved in a carbohydrate metabolism process via hydrolysis of the a-glycosidic bond among polysaccharide chain and release a single glucose molecule, which would be absorbed into the blood stream. Inhibition of this enzyme can slowdown the carbohydrate metabolism and lead to reduction of blood sugar level in the end (Van de Laar, 2008).

*Corresponding author. E-mail: sukanya.d@psu.ac.th or dejadisai@yahoo.com. Tel/Fax: +66-74-428220. Tel: +66-86-9687822. 
Borassus flabellifer Linn. has a common English name "Sugar palm". B. flabellifer is widely spread through Southern Asia including Bangladesh, India, Laos, Myanmar and Thailand, and it has different local names across this region such as "Tal", "Palmyra", "KoK mak tan", "Htan" and "Thann", respectively. Sugar palm has been used by traditional medicine according to the part of the plant, for example; root part treats aphthous ulcer, fever and helminthes; fresh petiole part is used as antidiarrhea (Siri Ruckhachati Nature Park, 2015).

$B$. flabellifer or sugar palm has been claimed traditionally to treat many disorders such as antiinflammatory activity, diuretic, sedative and laxative effects (Paschapur et al., 2009). Recently B. flabellifer was reported to have anti-diabetic activity in animal model and in inhibition of glucose transportation in in vitro study (Uluwaduge et al., 2005; Uluwaduge et al., 2006). However, it is possible that $B$. flabellifer may have more than one mechanism in reducing blood glucose level. Many phytochemical substances from natural products were found, a-glucosidase inhibition (Yin et al., 2014) which is the one of mechanism for anti-diabetes treatment. So, $B$. flabellifer is fascinating in the investigation of the $\alpha$-glucosidase inhibitory activity of the extracts and isolated compounds. This study will be the first report on a-glucosidase inhibitory activity and phytochemical study of $B$. flabellifer.

\section{MATERIALS AND METHODS}

\section{General experiment procedures}

UV spectra were prepared in methanol and obtained from a spectronic Genesys 6 and IR spectra were recorded on Perkin Elmer FT-IR by neat technique on $\mathrm{NaCl}$ dish. Moreover, NMR spectra were operated in suitable solvents such as deuterated chloroform, methanol and water on NMR spectrometer, Varian unity or Bruker, $300 \mathrm{MHz}$ or $500 \mathrm{MHz}\left({ }^{1} \mathrm{H}-\mathrm{NMR}\right)$ and $75 \mathrm{MHz}$ or 125 $\mathrm{MHz}\left({ }^{13} \mathrm{C}-\mathrm{NMR}\right)$, respectively and two dimension NMR including $\mathrm{HMQC}$ and $\mathrm{HMBC}$ were repeated on the same instruments. Mass spectra were obtained from two methods including electron impact mode from Thermofinnigan MAT $95 \mathrm{XL}$ mass spectrometer and electron spray ionization mode from Alliance - micromass Walters 2690 - LCT. The enzymatic reaction was determined at $405 \mathrm{~nm}$ on DTX 880 microplate reader. Column chromatography was undertaken on both silica gel $60 \mathrm{H}$ (Merck) and Sephadex ${ }^{\circledR} \mathrm{LH}-20$ (GE Healthcare). Thin layer chromatography analysis was performed on silica gel $60 \mathrm{GF}_{254}$ (Merck) using $50 \%$ sulphuric acid and anisaldehyde - sulphuric reagent as spraying reagents.

\section{Chemicals and reagents}

All solvents for extraction and isolation processes were purchased from Thail Oil Co. Ltd., Thailand. Alpha-glucosidase from Saccharomyces cerevisieae, para-nitrophenyl-alpha-Dglucopyranosidse and acarbose were obtained from Sigma-Aldrich, Germany.

\section{Plant material}

The fruits of sugar palm (B. flabellifer Linn.) were collected from
Singhanakorn district, Songkhla province, Thailand. The voucher specimen number of this plant was SKP 136/217 020601 . It was collected at the Department of Pharmacognosy and Pharmaceutical Botany, Faculty of Pharmaceutical Sciences, Prince of Songkla University, Songkhla, Thailand.

\section{Extraction and isolation}

The fresh sugar palm's fruits were cleaned. Their peels were removed and the yellowish pulps were cut into small pieces, and dried under hot-air oven at $60^{\circ} \mathrm{C}$ for 5 days. Next, all dried samples were macerated with 4 different solvents, which started with petroleum ether (Pet. ether), ethyl acetate (EtOAc), ethanol (EtOH) and water, respectively. In this step, samples were soaked in solvent for 3 days and then filtrated. The extract was dried by a rotary evaporator and water bath and the residues were remacerated twice before moved to next solvents. On water part, the samples were boiling at $70^{\circ} \mathrm{C}$ for $6 \mathrm{~h}$ instead of maceration. After drying, all extracts were kept at $4^{\circ} \mathrm{C}$ until determination.

The EtOH extract $(30 \mathrm{~g})$ was loaded over the silica gel (Merck, $0.063-0.2 \mathrm{~mm}$ ) on the quick column chromatography, which started with mobile phase with chloroform $\left(\mathrm{CHCl}_{3}\right) 100 \%$ until it reached 60:40:2 ratio of $\mathrm{CHCl}_{3}$, EtOAc and water. All fractions from the column were grouped into three fractions according to their thin layer chromatography (TLC) patterns. The second fraction (F2, 11.5 g) was further isolated by classical column chromatography. After three columns with same mobile system as before, but in different ratio as 70:30:2, one column of Sephadex ${ }^{\circledR} \mathrm{LH}-20$ (GE healthcare), compound $1(47 \mathrm{mg})$ was found.

The EtOAc extract also was isolated by two methods. Firstly, 30 $\mathrm{g}$ of the EtOAc extract was loaded on the normal phase quick column chromatography, which used the same solvents system like previous column. After evaluation by TLC pattern, all fractions were combined into five fractions. The second fraction (F2, $19.5 \mathrm{~g}$ ) was brought to the other columns to seek the pure components. After silica gel column chromatography, the crystals appeared on the fifth fraction (F25, $4.8 \mathrm{mg}$ ). So, the crystals were washed by methanol $(\mathrm{MeOH})$ and further purified by Sephadex ${ }^{\circledR} \mathrm{LH}-20$ columns, by using $\mathrm{CHCl}_{3}$ and $\mathrm{MeOH}$ with 50:50 ratio as the mobile phase. So, compound $2(2.5 \mathrm{mg})$ was received from this column. However, the first fraction of the second column (F21, $190 \mathrm{mg}$ ) showed possibility to isolate another component. Thus, F21 was further isolated with the normal phase and Sephadex ${ }^{\circledR}$ columns until compound 3 (5.3 $\mathrm{mg}$ ) was obtained. Secondly, the $3 \mathrm{~g}$ of this extract was solved with 50:50 mixtures of water and $\mathrm{MeOH}$ and it was partition with Pet. ether, EtOAc and $\mathrm{CHCl}_{3}$, consequently. Moreover, compound 4 (0.8 $\mathrm{mg}$ ) was found from the EtOAc partition part after two classical columns with $80: 20$ ratio of $\mathrm{CHCl}_{3}$ and EtOAc and one column of Sephadex ${ }^{\circledR}$ with 50:50 mixtures of $\mathrm{CHCl}_{3}$ and $\mathrm{MeOH}$.

\section{In vitro a-glucosidase inhibitory activity}

Alpha-glucosidase inhibition was determined for all extracts, which was performed following the previously report assays (Walker et al., 1995; Kim et al., 2008; You et al., 2011) This protocol would be described briefly subsequently. After hydrolysis reaction, a substrate such as $p$-nitrophenyl-alpha-D-glucopyranoside ( $p N P G)$ turned to $p$-nitrophenol as a product, which had a yellow color and could be detected at $405 \mathrm{~nm}$. Firstly, $50 \mu \mathrm{l}$ of $8 \mathrm{mg} / \mathrm{ml}$ sample solution were mixed in the wells with both $50 \mu \mathrm{l}$ of phosphate buffer solution, which had $2 \mathrm{mg} / \mathrm{ml}$ of bovine serum albumin and 0.2 $\mathrm{mg} / \mathrm{ml}$ sodium azide (PBS) and $50 \mu \mathrm{l} 1 \mathrm{unit} / \mathrm{ml}$ of $\alpha$-glucosidase enzyme in PBS. In the control well, $5 \%$ of DMSO solution was used. Moreover, $8 \mathrm{mg} / \mathrm{ml}$ of acarbose solution replaced the sample solution for positive control well. All wells were incubated at $37^{\circ} \mathrm{C}$ for 2 min before adding the $4 \mathrm{mM}$ of $p N P G$ into the mixed wells. 
Next, entire reaction was detected at $405 \mathrm{~nm}$ every half minutes for $5 \mathrm{~min}$ by micro-plate reader. The velocity of the reaction was performed (Equation 1) for calculation of the percent inhibition (Equation 2).

$$
\text { Velocity }=\frac{\Delta \text { Absorbance }}{\Delta \text { Time }}
$$

Inhibition $(\%)=\frac{V_{\text {control }}-V_{\text {sample or positive control }}}{V_{\text {control }}} \times 100$

The $\mathrm{IC}_{50}$ of all compounds was performed cover 6 concentrations starting at $1000 \mu \mathrm{g} / \mathrm{ml}$ and 3 - folds dilution technique was used. The relationships between concentrations and \% inhibition would show as a curve graph in both normal and semi - log scales. Furthermore, the $\mathrm{IC}_{50}$ values were determined following equation 3 , a non - linear relationship (Copeland, 2005) by SPSS version 22.0 program (SPSS Inc., Chicago, Illinois, USA).

Inhibition $(\%)=\frac{100}{1+\left({ }^{\prime} C_{50} / \text { Inhibitor conentration }\right)^{\text {hill slope }}}$

\section{RESULTS}

After extraction series of $B$. flabellifer (dried weight, 11.4 $\mathrm{kg}$ ), all extracts were weighted and calculated as $\%$ yield. As a result, EtOH extract showed the highest \% yield $(15.5 \%, 1.7 \mathrm{~kg})$. Water extract were the second $(3.64 \%$, $416 \mathrm{mg})$. Furthermore, the third and the last \% yield were on Pet. ether $(0.5 \%, 63.3 \mathrm{mg})$ and EtOAc extracts $(0.4 \%$, $54.7 \mathrm{mg}$ ), respectively. Next, all the samples were evaluated for a-glucosidase inhibitory activity (Figure 1). EtOAc had the strongest activity at $80.1 \pm 3.3 \%$ that was an equivalent activity to acarbose as standard drug (80.0 $\pm 3.2 \%)$. The moderate activity was found in both water and $\mathrm{EtOH}$ extracts as $55.5 \pm 3.8$ and $42.8 \pm 4.2 \%$, respectively.

To identify an inhibitors in active extracts, EtOAc and $\mathrm{EtOH}$ extracts were isolated by column chromatography techniques. After isolation and purification processes, four fractions were obtained; three pure compounds and one mixture component (Figure 2). Three pure compounds were glucosyl-(6-1)-glycerol (compound 1), 5-hydroxymethyl-furfural (compound 3) and tyrosol (compound 4). In addition, one mixture component was a mixture between $\beta$-sitosterol and stigmasterol (compound 2).

\section{Compound 1}

Compound 1 appeared as yellowish oil. The UV spectrum in $\mathrm{MeOH}$ showed absorption band at $\lambda_{\max } 202 \mathrm{mn}, 242$ (shoulder) and $284 \mathrm{~nm}$ (shoulder), and the IR peaks exhibited at $3367(-\mathrm{OH}), 2931\left(-\mathrm{CH}_{2}\right), 1419$ and $1363(-$ $\mathrm{CH}_{2}$ ) and $1076 \mathrm{~cm}^{-1}$ (-CO). The molecular formula of compound1 was determined as $\mathrm{C}_{9} \mathrm{H}_{18} \mathrm{O}_{8}$, which deducted which deducted from ESI-MS pseudo-ion peak at 277.1 $\mathrm{m} / \mathrm{z}\left[\mathrm{M}+\mathrm{Na}^{+}\right]$and NMR spectroscopic data, which would be showed next. The ${ }^{1} \mathrm{H}-\mathrm{NMR}$ spectrum showed signals in an anomeric region of the sugar moiety. The signals were found at $\delta 5.13(\mathrm{H}-1)$ and $4.55\left(\mathrm{H}-1^{\prime}\right)$, which indicated $\alpha-$ and $\beta$-glucopyranose molecules consequently.

First anomeric signal, $\delta 5.13(\mathrm{H}-1)$, showed small $\mathrm{J}$ value as $3.66 \mathrm{~Hz}$ and doublet in splitting pattern, which indicated a coupling constant between $\mathrm{H}-1$ and $\mathrm{H}-2$ of $\alpha$ glucopyranose. Second signal at $4.55\left(\mathrm{H}-1^{\prime}\right)$ had also the same splitting pattern (doublet) but larger $J$-value as 8.05 $\mathrm{Hz}$ than the previous anomeric signal that was a characteristic coupling constant between $\mathrm{H}-1$ " and $\mathrm{H}-2$ " of $\beta$-glucopyranose. After that, the remaining protons on both $\alpha$ and $\beta$-isomer were determined based on COSY spectrum and the previous report (13) that were shown in Table 1. Finally, the last four signals at $\delta 3.75(2 \mathrm{H}, \mathrm{d}, J=$ $7.82 \mathrm{~Hz}), 3.78(1 \mathrm{H}, \mathrm{m}), 3.63(1 \mathrm{H}, \mathrm{dd}, J=5.88$ and 12.44 $\mathrm{Hz})$ and $3.70(1 \mathrm{H}$, dd, $J=6.84$ and $13.42 \mathrm{~Hz})$ were identified as protons of glyceryl part that were determined at $\mathrm{H}-1$ "' to $\mathrm{H}-3$ "'A and $\mathrm{B}$, consequently (14). Next, the ${ }^{13} \mathrm{C}$ NMR spectrum showed fifteen signals. Two signals at $\delta$ 89.49 (C-1) and 93.31 (C-1") were assigned as anomeric carbons of $\alpha$-glucopyranose and $\beta$-glucopyranose, respectively. The other signals were assigned by comparison with the previous report (13). The last three signals were defined as carbons of glyceryl residue including $\delta 66.77,68.85$ and 60.62 , which were C-1"' to C-3"' (15). Finally, the linkage bonds between glucopyranosyl and glyceryl structures were indicated by HMBC. According to the entire spectroscopic data, mass spectrum and by comparing all spectroscopic data with the previous reports (Bondu et al., 2007; Goffin et al., 2009; Pretsch et al., 2009; Nihira et al., 2014), compound 1 was identified as glucosyl-(6-1)-glycerol. The summary NMR spectrum of compound 1 was shown on Table 1.

\section{Compound 2}

Compound 2 is colorless needles. The UV spectrum in $\mathrm{MeOH}$ showed absorption band at $\lambda_{\max } 202$ and $238 \mathrm{~nm}$ (shoulder), IR ( NaCl, neat) $3363(-\mathrm{OH}), 2933$ and 2863 $\mathrm{cm}^{-1}\left(-\mathrm{CH}_{3}\right.$ and $\left.-\mathrm{CH}_{2}\right), 1679(\mathrm{C}=\mathrm{C}), 1457$ and $1374\left(-\mathrm{CH}_{3}\right.$ and $\left.-\mathrm{CH}_{2}\right)$ and $1051 \mathrm{~cm}^{-1}(-\mathrm{CO}),{ }_{1}^{1} \mathrm{H}-\mathrm{NMR}(500 \mathrm{MHz}$, $\mathrm{CDCl}_{3}$ ) and ${ }^{13} \mathrm{C}-\mathrm{NMR}\left(125 \mathrm{MHz}, \mathrm{CDCl}_{3}\right.$ ) were in close agreement with the recent published article (AbdelWahab et al. 2014). So, compound 2 was established as a mixture of $\beta$-sitosterol and stigmasterol.

\section{Compound 3}

Compound 3 is yellowish oil, The UV spectrum in $\mathrm{MeOH}$ showed absorption band at $\lambda_{\max } 202 \mathrm{~nm}, 222$ 


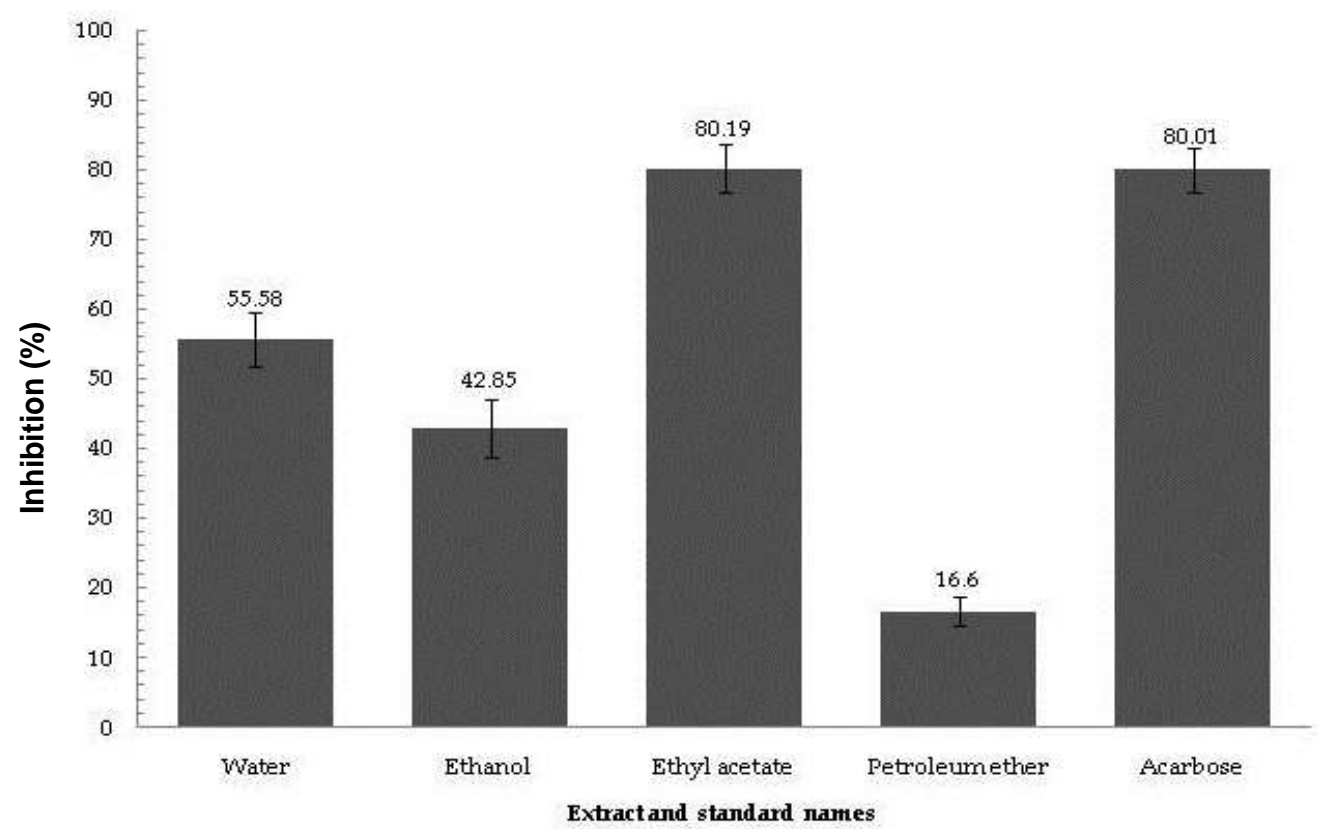

Figure 1. Alpha-glucosidase inhibitory activity of $B$. flabellifer extracts and standard drug, acarbose.

(shoulder) and $280 \mathrm{~nm}$. IR ( $\mathrm{NaCl}$, neat) $3366(-\mathrm{OH}), 2924$ and $2815 \mathrm{~cm}^{-1}\left(-\mathrm{CH}_{2}\right), 1734(-\mathrm{C}=\mathrm{O}), 1672(\mathrm{C}=\mathrm{C}), 1419(-$ $\mathrm{CH}_{2}$ ) and $1188 \mathrm{~cm}^{-1}(-\mathrm{CO}) .{ }^{1} \mathrm{H}-\mathrm{NMR}\left(500 \mathrm{MHz}, \mathrm{CD}_{3} \mathrm{OD}\right)$ $\delta_{\mathrm{H}} 9.53(\mathrm{H}-1,1 \mathrm{H}, s), \delta_{\mathrm{H}} 7.37(\mathrm{H}-3,1 \mathrm{H}, d, J=3.50 \mathrm{~Hz}), \delta_{\mathrm{H}}$ $6.57(\mathrm{H}-4,1 \mathrm{H}, d, J=3.50 \mathrm{HZ})$ and $\delta_{\mathrm{H}} 4.60(\mathrm{H}-6,2 \mathrm{H}, s)$. ${ }^{13} \mathrm{C}-\mathrm{NMR}\left(125 \mathrm{MHz}, \mathrm{CD}_{3} \mathrm{OD}\right) \delta_{\mathrm{C}} 179.42(\mathrm{C}-1), \delta_{\mathrm{C}} 163.23$ $(\mathrm{C}-5), \delta_{\mathrm{C}} 153.98(\mathrm{C}-2), \delta_{\mathrm{C}} 124(\mathrm{C}-4), \delta_{\mathrm{C}} 110(\mathrm{C}-3)$ and $\delta_{\mathrm{C}}$ 57.65 (C-6). El-MS m/z 125.9 (97), 108.9 (97), 96.9 (70) and 69.0 (41). The spectroscopic data was confirmed with previous report (Khalil et al., 2003). So, compound 3 was 5-hydroxymethyl-furfural.

\section{Compound 4}

Compound 4 is a yellowish powder. The UV spectrum in $\mathrm{MeOH}$ exhibited $\lambda_{\max }$ at $202 \mathrm{~nm}, 224$ and $178 \mathrm{~nm}$. The IR spectrum showed several peaks at $3369(-\mathrm{OH}), 2919$ and $2845\left(-\mathrm{CH}_{2}\right.$ and $\left.-\mathrm{CH}_{3}\right), 1697$ (overtone of $=\mathrm{CH}$ ), 1596 and $1384 \mathrm{~cm}^{-1}$ (aromatic $\left.\mathrm{C}=\mathrm{C}\right), 1121(-\mathrm{CO})$ and $828 \mathrm{~cm}^{-1}$ $(=\mathrm{CH})$. The molecular compound $\left(\mathrm{C}_{8} \mathrm{H}_{10} \mathrm{O}_{2}\right)$ was deducted from NMR data and El-MS that showed the molecular ion peak at $138 \mathrm{~m} / \mathrm{z}\left[\mathrm{M}^{+}\right.$, base peak at $107 \mathrm{~m} / \mathrm{z}$ $\left[\mathrm{M}-\mathrm{CH}_{2} \mathrm{OH}\right]^{+}$and aromatic peak at $77 \mathrm{~m} / \mathrm{z}\left[\mathrm{M}-\mathrm{H}_{2} \mathrm{O}-\right.$ $\left.\mathrm{C}_{2} \mathrm{H}_{5} \mathrm{OH}\right]^{+}$. Moreover, the $1 \mathrm{H}-\mathrm{NMR}$ spectrum exhibited important signals in aromatic region at $\delta_{H} 7.00(\mathrm{H}-2$ and $5,2 \mathrm{H}, d, J=8.54 \mathrm{~Hz})$ and $\delta_{\mathrm{H}} 6.67(\mathrm{H}-3$ and $6,2 \mathrm{H}, \mathrm{d}, \mathrm{J}=$ $8.66 \mathrm{~Hz}$ ). This information indicated aromatic structure with para - substitution. In addition, other signals appeared at $\delta \mathrm{H} 3.66(\mathrm{H}-8,2 \mathrm{H}, \mathrm{t}, \mathrm{J}=7.20 \mathrm{~Hz})$ and $\square \mathrm{H}$ $2.69(\mathrm{H}-7,2 \mathrm{H}, \mathrm{t}, \mathrm{J}=7.14 \mathrm{~Hz})$.

These signals were assigned as an ethyl alcohol, connected with phenyl structure. After matching all information with a recent report, compound 4 could be determined as tyrosol (Guzmán-López et al.,

2007).

In in vitro, $\alpha$-glucosidase inhibitory activity and $\mathrm{IC}_{50}$ determination, all isolation of compounds took place for identification of inhibitors and the results were reported visually in concentrations response curve (Figure $3 \mathrm{~A}$ and B).

Firstly, the maximum concentration of all samples started at $1000 \mu \mathrm{g} / \mathrm{ml}$ and 3-folds dilution was used to dilute concentrations of all until reaching last concentration, $4.1 \mu \mathrm{g} / \mathrm{ml}$. As a result, acarbose (positive control), tyrosol (compound 4) and glucosyl-(6-1)-glycerol (compound 1) could inhibit $\alpha$-glucosidase enzyme in dose dependent manner.

Starting with standard drug, acarbose demonstrated the highest activity at $\mathrm{IC}_{50}$ of $125.6 \pm 9.3 \mu \mathrm{g} / \mathrm{ml}$ and hill coefficient of acarbose was 0.6. In addition, tyrosol showed the moderate inhibitory activity with this enzyme at $\mathrm{IC}_{50}$ value as $1041.2 \pm 203.5 \mu \mathrm{g} / \mathrm{ml}$ and hill coefficient of tyrosol was 0.3 , which was lower than acarbose. Lastly, glucosyl-(6-1)-glycerol also could inhibit $\alpha-$ glucosidase enzyme but with mild activity, 29.2\% inhibition at the concentration of $1000 \mu \mathrm{g} / \mathrm{ml}$ (Table 2). Fortunately, glucosyl-(6-1)-glycerol had enough amounts for further investigation while the others were not. So, the concentration of glucosyl-(6-1)-glycerol was enhanced from $1000 \mu \mathrm{g} / \mathrm{ml}$ to $4000 \mu \mathrm{g} / \mathrm{ml}$ for IC50 evaluation once again. Same as before, the 3-folds diluted protocol was applied until the lowest concentration became $16.4 \mu \mathrm{g} / \mathrm{ml}$. Finally, the IC50 value of glucosyl-(6-1)-glycerol was obtained at $4000.0 \pm 687.0 \mu \mathrm{g} / \mathrm{ml}$ with hill coefficient at 0.5 values, which closed to acarbose. 
<smiles>[R]C1([R])OC(COCC(O)CO)C(O)C(O)[C@H]1O</smiles>

$\beta$ form; $\mathrm{R}_{1}=\mathrm{OH}$ and $\mathrm{R}_{2}=\mathrm{H}$

$\alpha$ form; $\mathrm{R}_{1}=\mathrm{OH}$ and $\mathrm{R}_{2}=\mathrm{OH}$

(1)<smiles>O=Cc1ccc(CO)o1</smiles>

(3)<smiles>CCC(CC[C@H](C)C1CCC2C3CC=C4C[C@@H](O)CCC4(C)C3CCC21C)C(C)C</smiles>

(2)<smiles>OCCc1ccc(O)cc1</smiles>

(4)

Figure 2. Four isolated compounds from B. flabellifer: (1) Glucosyl-(6-1)-glycerol (compound 1); (2) the mixture of $\beta$-sitosterol and stigmasterol (compound 2); (3) 5 -hydroxymethylfurfural (compound 3) and (4) tyrosol (compound 4).

Table 1. ${ }^{1} \mathrm{H}-{ }^{13} \mathrm{C}$ NMR of glucosyl-(6-1)-glycerol (compound 1).

\begin{tabular}{lcccc}
\hline \multirow{2}{*}{ Position } & ${ }^{13}$ C-NMR & \multicolumn{3}{c}{${ }^{1}$ H-NMR } \\
\cline { 2 - 5 } & $\delta$ & $\delta$ & Pattern & J value \\
\hline 1 & 89.49 & 5.13 & $\mathrm{~d}$ & 3.66 \\
2 & 68.89 & 3.44 & $\mathrm{dd}$ & $3.66 / 9.52$ \\
3 & 70.17 & 3.62 & $\mathrm{dd}$ & $9.52 / 9.76$ \\
4 & $67.07^{*}$ & 3.31 & $\mathrm{t}$ & 9.52 \\
5 & $68.28^{*}$ & 3.73 & $\mathrm{ddd}$ & $10.00 / 5.37 / 2.40$ \\
$6 \mathrm{~A}$ & $58.02^{*}$ & 3.58 & $\mathrm{dd}$ & $6.59 / 12.21$ \\
$6 \mathrm{~B}$ & & 3.81 & $\mathrm{dd}$ & $2.20 / 12.20$ \\
$1^{\prime}$ & 93.31 & 4.55 & $\mathrm{~d}$ & 8.05 \\
$2^{\prime}$ & 71.55 & 3.15 & $\mathrm{dd}$ & $8.05 / 9.27$ \\
$3^{\prime}$ & 73.35 & 3.39 & $\mathrm{t}$ & 9.2 \\
$4^{\prime}$ & $67.02^{*}$ & 3.30 & $\mathrm{dd}$ & $9.27 / 9.58$ \\
$5^{\prime}$ & $73.17^{*}$ & 3.37 & $\mathrm{ddd}$ & $9.27 / 4.89 / 2.20$ \\
$6^{\prime} \mathrm{A}$ & $58.17^{*}$ & 3.67 & $\mathrm{dd}$ & $5.37 / 12.21$ \\
$6^{\prime} \mathrm{B}$ & & 3.81 & $\mathrm{dd}$ & $2.20 / 12.20$ \\
$1^{\prime \prime}$ & $66.77^{*}$ & $3.75^{*}$ & $\mathrm{~d}$ & 7.82 \\
$2^{\prime \prime}$ & $68.85^{*}$ & 3.78 & $\mathrm{~m}$ & - \\
$3^{\prime \prime}$ & $60.62^{*}$ & 3.63 & $\mathrm{dd}$ & $5.88 / 12.44$ \\
& & 3.70 & $\mathrm{dd}$ & $6.84 / 13.42$ \\
\hline
\end{tabular}

*Show the ${ }^{1} \mathrm{H}-{ }^{13} \mathrm{C}$ correlation on the structure base on HMBC data. 
Table 2. The $\mathrm{IC}_{50}$ determination of isolated compounds from $B$. flabellifer.

\begin{tabular}{lcccc}
\hline Compound Name & $\begin{array}{c}\mathbf{I C}_{50} \\
(\boldsymbol{\mu} \mathbf{g} / \mathbf{m})\end{array}$ & $\begin{array}{c}\text { Standard } \\
\text { error }(\mathrm{SE})\end{array}$ & $\begin{array}{c}\text { Hill } \\
\text { coefficient }\end{array}$ & $\begin{array}{c}\text { Maximum inhibition at } \\
\text { the highest concentration }(\%)\end{array}$ \\
\hline Acarbose & 125.6 & 9.3 & 0.6 & 81.0 \\
Tyrosol & 1041.5 & 205.5 & 0.3 & 51.7 \\
Glucosyl-(6-1)-glycerol & 4000.0 & 687.0 & 0.5 & 50.0 \\
& $>1500.0$ & - & - & 29.2 \\
Mixture of steroids & $>1500.0^{\ddagger}$ & - & - & 13.1 \\
$5-$ Hydroxymethyl - furfural & $>1500.0^{\ddagger}$ & - & - & 8.9 \\
\hline
\end{tabular}

${ }^{\ddagger}$ Indicate insufficient amount for testing.
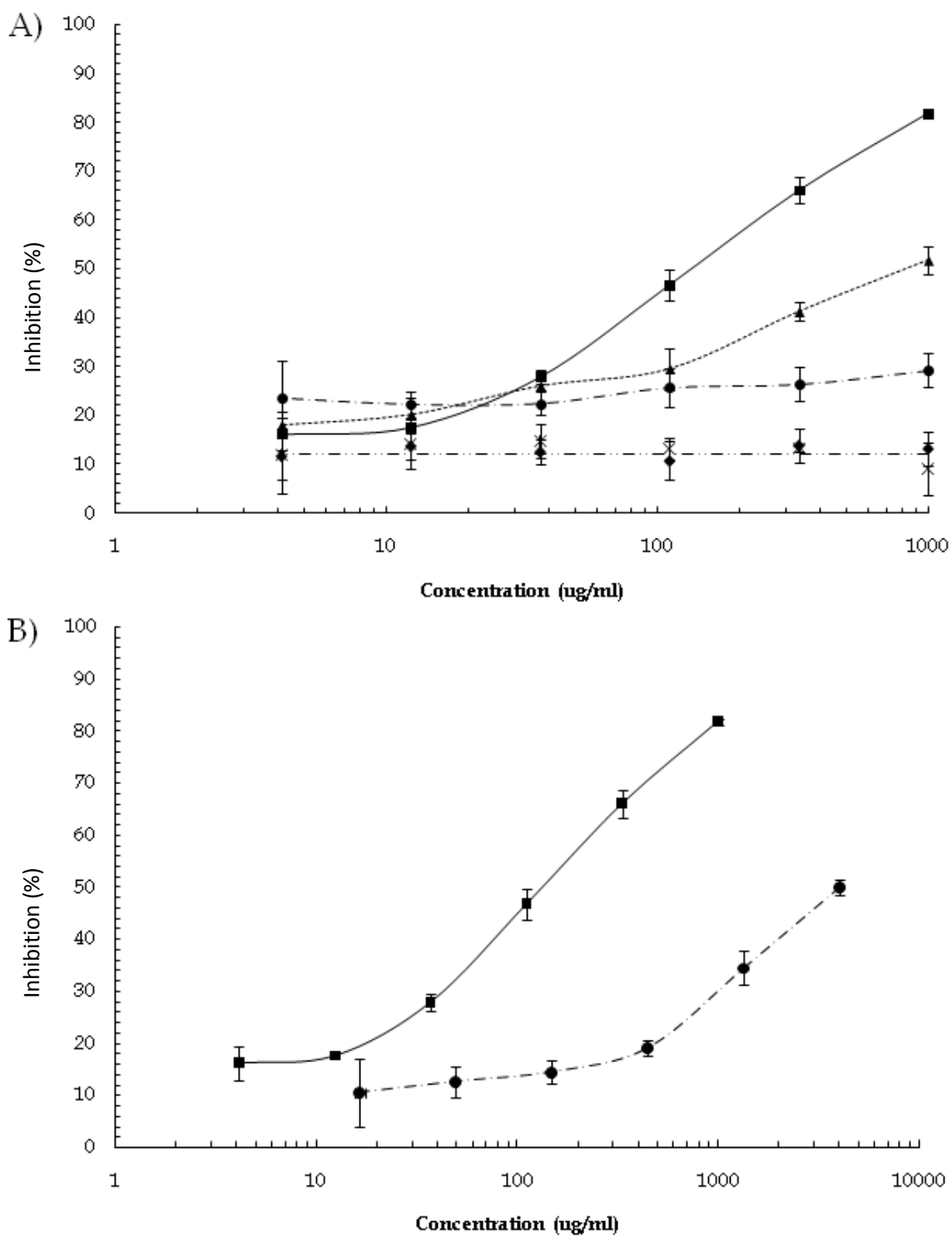

Figure 3. A) The concentration response curve at $1000 \mu \mathrm{g} / \mathrm{ml}$ of isolated compounds, as glucosyl-(6-1)-glycerol (Compound $1 ; 0)$, the mixture of $\beta$-sitosterol and stigmasterol (Compound 2; $\bullet$ ), 5-hydroxymethyl-furfural (Compound 3; *), tyrosol (Compound 4; $\Delta$ ), and standard drug (acarbose; $\mathbf{0}$ ); B) The semi-log curve of the concentration response curve at $4000 \mu \mathrm{g} / \mathrm{ml}$ of glucosyl-(6-1)-glycerol (Compound 1; ) as compared to standard drug (acarbose; $\mathbf{a})$ at $1000 \mu \mathrm{g} / \mathrm{ml}$. 


\section{DISCUSSION}

In summary, the EtOAc extract of $B$. flabellifer could inhibit $\alpha$-glucosidase like acarbose in the screening step at $80 \%$ inhibition, while water and $\mathrm{EtOH}$ extracts inhibited the same enzyme at lower potency, 55.5 and $42.8 \%$ inhibition, respectively (Figure 1). After phytochemical investigation of EtOAc and EtOH extracts, four components were found as glucosyl-(6-1)-glycerol (compound 1), the mixture of $\beta$-sitosterol and stigmatosterol (compound 2), 5-hydroxymethyl-furfural (compound 3) and tyrosol (compound 4), which are shown in Figure 2. However, only two compounds could inhibit $\alpha$-glucosidase. Firstly, tyrosol exhibited the lower $I_{50}$ value than glucosyl-(6-1)-glycerol (1041.2 \pm 203.5 and $4000.0 \pm 687.0 \mu \mathrm{g} / \mathrm{ml}$, accordingly). However, tyrosol had a smaller structure, at $138 \mathrm{~g} / \mathrm{mol}$, when compared with the structure of glucosyl-(6-1)-glycerol, which was 254.23 $\mathrm{g} / \mathrm{mol}$. Based on this fact, the activity of both compounds was almost close to others in term of molarity as 15.73 $\mathrm{mM}$ for tyrosol and $9.60 \mathrm{mM}$ for glucosyl-(6-1)-glycerol, respectively (Figure 3 ). In detail, hill coefficient values had been used commonly in pharmacology to evaluate the stoichiometric interaction between inhibitor and target enzyme, which could give clue about the behavior of inhibitor (Copeland, 2005). Tyrosol had hill coefficient value lower than acarbose, which was known as a competitive behavior that one molecule of inhibitor could bind at one active site of enzyme. The lower hill value of tyrosol might indicate that tyrosol more than one molecule could interact with an enzyme, which was possibly a behavior of non-competitive inhibitor. Next, glucosyl-(6-1)-glycerol had a hill coefficient value was almost close to that of acarbose. So, it was possible that glucosyl-(6-1)-glycerol could have the same behavior like acarbose. Moreover, the structure of glucosyl-(6-1)glycerol could also be used to support this finding because its structure was interpreted as a carbohydrate derivative.

In addition, the result of this study showed the correlation with the recent reports. The previous reports showed that $B$. flabellifer could reduce the blood sugar level in animal model (Uluwaduge et al., 2006) and in clinical pilot study (Uluwaduge et al., 2008). Besides, the mechanism that might be response was reported as $\mathrm{Na} / \mathrm{K}$ ATPase (Uluwaduge et al., 2005), which involved the glucose transportation process from intestinal lumen to blood stream. The steroidal saponins were claimed as a active components (Ariyasena et al., 2010). Moreover, the findings in this study demonstrated the other possible mechanism ( $\alpha$-glucosidase inhibition), which is also involved in carbohydrate metabolism process, and active components (tyrosol as phenolic compound) that could be response in anti-diabetes activity of $B$. flabellifer.

Eventually, it is quite clear that $B$. flabellifer has potency in anti-diabetes activity according to the scientific evidences until now. Moreover, the results of this study also supported that $B$. flabellifer extracts and its components could inhibit $\alpha$-glucosidase that was one of mechanisms for lowing blood sugar because there are many mechanisms, which can reduce glucose level.

\section{Conclusion}

$B$. flabellifer extract and the isolated compounds, tyrosol and glucosyl-(6-1)-glycerol showed $\alpha$-glucosidase inhibitory activity. Further, the plant has to be explored for anti-diabetic activities.

\section{Conflict of Interests}

The authors do not have any conflict of interest for this work.

\section{ACKNOWLEDGEMENTS}

The authors thank the Faculty of Pharmaceutical Sciences, Prince of Songkla University for the laboratory and equipment. Financial support by Plant Genetic Conservation Project under The Royal Initiative of Her Royal Highness Princess Maha Chakri Sirindhorn (RSPG) in this work is acknowledged.

\section{REFERENCES}

Abdel-Wahab NM, Hamed ANE, Khalil HE, Sang MN, Wanas AS, Fouad MA, Kamel MS (2014). Phenolic acid glycoside from Pamentiera cereifera Seem. (Candle tree). Phytochem. Lett. 9:74-77.

Ariyasena DD, Janz ER, Baeck P (2010). Direct isolation of flabelliferins of palmyrash by MPLC. J. Nat. Sci. Found Sri Lanka. 30:55-60.

Bondu S, Kervarec N, Deslandes E, Pichon R (2007). Separation of floridoside and isofloridosides by HPLC and complete ${ }^{1} \mathrm{H}$ and ${ }^{13} \mathrm{C}$ NMR spectral assignments for D -isofloridoside. Carbohydr. Res. 342(16):2470-2473.

Chan JCN, Cha NH, Taijima N, Shawn J (2014). Diabetes in the Wastern Pacific Region - past, present and future. Diabetes Res. Clin. Pract. 103:244-255.

Copeland RA (2005). Evaluation of enzyme inhibitors in drug discovery: a guide for medicinal chemists and pharmacologists. Methods Biochem. Anal. 46:1-265.

Goffin D, Bystricky P, Shashkov A, Lynch M, Hanon E, Paquot M, Savage A (2009). A systematic NMR determination of $a-D$ glucooligosaccharides, effect of linkage type, anomeric configuration and combination of different linkages type on ${ }^{13} \mathrm{C}$ chemical shifts for the determination of unknown isomaltooligosaccharides. Bull. Korean Chem. Soc. 30(11):2535-2541.

Guariguata L, Whiting DR, Hambleton I, Beagley J, Linnenkamp U, Shaw JE (2014). Global estimates of diabetes prevalence for 2013 and projections for 2035. Diabetes Res. Clin. Pract. 103:137-149.

Guzmán-López O, Trigos Á, Fernández FJ, de Jesús Yañez-Moralaes M, Saucedo-Castañeda G (2007). Tyrosol and tryptophol produced by Ceratocystis adipose. World J. Microbiol. Biotechnol. 23:1473-1477.

Khali AT, Chang FR, Lee YH, Chen CY, Liaw CC, Ramesh P, Yuan SSF, Wu YC (2003). Chemical constituents from the Hydrangea chinensis. Arch. Pharm. Res. 26:15-20.

Kim YK, Nam AK, Kurihara H, Kim MS (2008). Potent a-glucosidase inhibitors purified from the red algae Grateloupia. elliptica. Phytochemistry 60:2820-2825.

Nihira T, Saito Y, Ohtsubo KI, Nakai H, Kitaoka M (2014). 2-O-a-Dglucosylglycerol phosphorylase from Bacillus selenitireducens MLS10 possessing hydrolytic activity on $\beta$-D-glucose-1-phosphate. Plos One 
$9(1): 1-10$.

Paschapur MS, Patil MB, Kumar R, Patil SR (2009). Evaluation of anti inflammatory activity of ethanolic extract of Borassus flabelliferin $\mathrm{L}$. male flowers (inflorescences) in experimental animals. J. Med. Plants. Res. 3(2):49-54.

Pretsch E, Bühlmann P, Badertscher M (2009). Structure determination of organic compounds. $4^{\text {th }}$ ed. Berlin, Heidelberg: Springer Berlin Heidelberg. Available at: http://www.springer.com/gp/book/9783540938095

Siri Ruckhachati Nature Park. 2015. Accessed December 6, 2015. http://www.pharmacy.mahidol.ac.th/ siri/index.php?page $=$ search detail\&medicinal id $=379$.

Uluwaduge I, Parera A, Janszn E, Thabrew I (2008). A pilot study on palmyrah pinattu (dried fruit pulp) as an anti- diabetic food component. Int. J. Biol. Chem. Sci. 1:250-254.

Uluwaduge I, Punya AA, Senadheera SN, Jansz ER (2005). Studies on the natural hydrophobic blinder of flabelliferins and their effect on some bioactivities. J. Natl. Sci. Found.- Sri Lanka. 33:187-191.
Uluwaduge I, Thabrew MI, Janz ER (2006). The effect of flabelliferins of palmyrah fruit pulp on intestinal glucose uptake in mice. J. Natl. Sci. Found. Sri Lanka. 34:37-41.

Van de Laaar FA (2008). Alpha - glucosidase inhibitors in the early treatment of type 2 diabetes. Vasc. Health Risk Manag. 4:1189-1195.

Walker JM, Winder JS, Kellam SJ (1995). Highthroughput micro titer plate-based chromogenic assays for glycosidase inhibitors. Appl. Biochem. Biotech. 38:141-146.

Yin Z, Zhang W, Feng F, Zhang Y, Kang W (2014). Alpha - glucosidase inhibitors isolated from medicinal plants. Food Sci. Hum. Wellness. 3:136-174.

You Q, Chen F, Wang X, Luo PG, Jiang Y (2011). Inhibitory effects of muscadine anthocyanins on $\alpha$ - glucosidase and pancreatic lipase activities. J. Agric. Food Chem. 59:9506-9511. 